teaching bibliography; and/or active participation in organizations devoted to the promotion and enhancement of bibliographic instruction. (Nominees do not have to meet all of the stated criteria.)

Letters of nomination should outline the nominee's achivements according to the above criteria and, if possible, a curriculum vitae of the nominee should be attached. Nominations should be sent no later than December 1, 1987, to Betsy Baker, Bibliographic Instruction Services Librarian, Northwestern University Library, 1935 Sheridan Road, Evanston, IL 60201; (312) 491-7656.

\title{
The Down Under experience
}

\author{
By Joan I. Tracy \\ Assistant Librarian for Technical Services \\ Eastern Washington University
}

\section{A cataloger's adventures in Australia.}

$\mathbf{M}$ Library of the University of Queensland resulted from inquiries to Australian libraries that had been listed in C\&RL News as potential exchange institutions. Because of my administrative responsibilities, I could not offer an exchange of positions, but I was willing to work in any professional capacity in technical services. In turn, the Eastern Washington University Library would offer a position in technical services with an emphasis on cataloging.

My inquiries elicited a reply from the deputy librarian at the University of Queensland, who indicated that Gillian Meteyard, a cataloger at the Central Library, was interested in an exchange. After the exchange was approved, Gillian and I then corresponded to arrange a swap of our homes and the use of our cars for April through September 1986.

The technical services staff of about 60 in Queensland's Central Library performs the familiar tasks of ordering, cataloging and processing library materials. The large staff, in contrast to similar libraries in the United States, is a result of the policy of hiring full-time employees to do much of the work that is performed by part-time student assistants in American academic libraries.

The catalogers are organized into teams, with each group responsible for several subject areas so that the workload is equitably distributed. I was a member of the "Purple" team that processed all materials for the Q-QE, HA-HG, and PC class numbers of the Library of Congress schedule. The team included two librarians and two library assistants. The group processed all orders and cataloged all materials, including serials, government documents and audiovisual items (the latter from surrogates prepared by other staff). However, I cataloged only monographs.

The use of AACR2 and the Library of Congress classification and subject headings made it relatively easy for me to jump right in and make myself useful. However, it took me a while to learn local practice, including such minor details as entering a date in the Australian pattern with the day first, and writing the LC call number in a different format. The team leader, the two library assistants, and everyone in the cataloging area were forgiving of my errors and always ready to answer my questions.

When I first began work that April, cataloging was obtained from the Australian National Library (ANL) by matching search keys: ISBN, LC card number, author and title. However, a few months later the cataloging teams began to access 
LC cataloging on Bibliofile. In each case a printout of the record was obtained for editing, at first from the ANL and later from Bibliofile via the library's own computer. About half of the printouts required considerable editing to conform to the library's cataloging standards, especially authority control. Approximately $40 \%$ of the titles required original cataloging because they were in a nonEnglish language (mostly not available on Bibliofile) or because they were recent Australian or other imprints that took a long time to appear in Bibliofile. Edited printouts and worksheets of original cataloging were forwarded to a team of data entry operators.

Products, including cards and labels, were produced by the library's computer (Digital Equipment Corporation PDP 11/73). A circulation system had been installed some years earlier, so that as older items were converted from the previously used Dewey call numbers, the circulation and bibliographic records were linked. Great care was taken with authority work to insure consistency in name access points. A large card file was maintained with the authority records for all names (personal and corporate) and series.

Because of severe space limitations in the Central Library, the cataloging teams spent a good deal of time processing books for "store" (warehouses in downtown Brisbane). Implementation of the first stages of an online public access catalog (OPAC) was planned for the near future, with several terminals to be installed in the Central Library. All of this automation has been developed in-house, by a library computer staff that includes a systems analyst, two programmers, and a computer operator. This in-house approach contrasts with the situation at Eastern Washington, and probably most other U.S. academic libraries, where automation has been implemented through the purchase of existing systems or contracts for their use.

Because of the large staff, working arrangements in the library were more formal than I had been used to, with a sign-in sheet and tea breaks at a set hour. The tea lady in the staff room would have been overwhelmed if everyone had appeared at the same time. A pleasant surprise was the 7hour working day, with the opportunity of accumulating "flextime" for long weekends. Since every worker in Australia has four weeks of vacation, I took a week off in July and another in September.

The annual winter luncheon for the technical services department, held in August, included a surprise for me. I was initiated into the "Vegemites" named after that Australian delicacy) and presented with a keepsake album, complete with catalog cards and labels!

\section{8/89 Management Intern Program}

The Council on Library Resources (CLR) has called for applications for its 1988/89 Academic Library Management Intern Program. Up to three interns will be selected to spend nine months working with the directors and staffs of major academic libraries. While individual programs vary in detail, interns observe and participate in management activities and often undertake special assignments. As a result of this experience, they gain a comprehensive overview of the knowledge and skills required of library directors.

Grants to interns include salary and benefits up to a maximum of $\$ 30,000$ for the nine-month period. Some additional assistance is provided for program-related costs and moving expenses.

The internship offers an exceptional opportunity for individuals with management aspirations to add to their experience and skills. Although there is no guarantee that participation will result in professional advancement, the program has helped to expand the pool of highly qualified librarians seeking to move into senior administrative posts.

Applicants must be citizens of the U.S. or Canada, or have permanent resident status in either country. Interns will be chosen by a selection committee, which will consider such factors as professional library experience, administrative skills, ac- ademic record, and the intellectual and personal qualities that are important in academic library leadership. Finalists will be invited to Washington for personal interviews.

Applications for the 1988/89 academic year must be postmarked no later than November 2, 1987. For further information and application forms, write to the Academic Library Management Intern Program, Council on Library Resources, 1785 Massachusetts Avenue, N.W., Washington, DC 20036.

\section{Vendor performance}

The RTSD Serials Section Acquisitions Committee is developing guidelines for serial and periodical vendor performance evaluation. Has your library performed evaluations, formal or informal, of such vendors? Please send examples of your criteria and/or procedures, or sample studies. Comments, ideas, and half-formed thoughts are welcome. Respond to: Lynn $\mathrm{M}$. Cummins, Library, Acquisitions/Serials Department, California State University, Northridge, 18111 Nordhoff Street, Northridge, CA 91330. 